\title{
PENERAPAN METODE BERMAIN JARI ANGKA UNTUK MENINGKATKAN KEMAMPUAN BERHITUNG ANAK USIA DINI PADA KELOMPOK B
}

\author{
Sartika Nur Alwy ${ }^{1}$, Iis Jubaedah ${ }^{2}$, Fifiet Dwi Tresna Santana ${ }^{3}$ \\ ${ }^{1}$ IKIP Siliwangi, Cimahi \\ ${ }^{2}$ IKIP Siliwangi, Cimahi \\ ${ }^{3}$ IKIP Siliwangi, Cimahi \\ 19alwy.sartika@gmail.com,${ }^{2}$ iisjubaedah100@gmail.com,${ }^{3}$ fifiet@,ikipsiliwangi.ac.id
}

\begin{abstract}
Penelitian ini menggunakan metode quasi experiment dilaksanakan di RA Alkaromah Cimahi. This research is based on findings in the field of learning to count for young children who are not quite right, playing with numbers is a new method used to make it easier for children to follow arithmetic, using fingers children tend to be more interested and passionate in learning to count, play this is done very simply starting with introducing fingers, numerical symbols, and fine motor and gross motor activities in early childhood. The purpose of this study is in accordance with the findings in the field that how to learn to count children in RA Alkaromah is less effective, so researchers try to provide a new method that is the method of playing the number fingers to make it easier for the numeric fingers to make it easier for children to learn to play counting. The ability of children in RA Alkaromah in counting after knowing the method of finger playing this number is improved better than before using the method of finger play these numbers can be seen from the results of the study before being given the results obtained 31,7500 while after giving treatment by researchers the results obtained are 32.0625 .
\end{abstract}

\section{Keywords: Play, Finger Numbers, Numeracy Skills, Early Childhood.}

\begin{abstract}
Abstrak
Penelitian ini menggunakan metode quasi experiment dilaksanakan di RA Alkaromah Cimahi. Penelitian ini didasari oleh temuan di lapangan pada pembelajaran bermain berhitung pada anak usia dini yang kurang tepat, bermain jari angka adalah metode baru yang digunakan untuk memudahkan anak dalam mengikuti berhitung, dengan menggunakan jari anak anak cenderung lebih tertarik dan semangat dalam mengikuti pembelajaran berhitung, permainan ini dilakukan dengan sangat sederhana dimulai dengan mengenalkan jari tangan, simbol angka, dan kegiatan motorik halus dan motorik kasar pada anak usia dini. Tujuan penelitian ini adalah sesuai hasil temuan di lapangan bahwa cara belajar berhitung anak di RA Alkaromah kurang efektif sehingga peneliti mencoba memberikan metode baru yaitu metode bermain jari angka untuk lebih memudahkan jari angka untuk lebih memudahkan anak dalam proses pembelajaran bermain berhitung. Kemampuan anak di RA Alkaromah dalam berhitung setelah mengenal metode bermain jari angka ini menjadi meningkat lebih baik dari sebelum menggunakan metode bermain jari angka tersebut hal ini terlihat dari hasil penelitian sebelum diberikan treatment diperoleh hasil 31.7500 sedangkan setelah pemberian treatment oleh peneliti diperoleh hasil 32.0625 .
\end{abstract}

Kata kunci: Bermain, Jari Angka, Kemampuan Berhitung, Anak Usia Dini. 


\section{JURMAL GERIA}

ISSN : 2614-6347 (Print) 2714-4107 (Online)

Vol.2 | No.6 | September 2019

\section{PENDAHULUAN}

"Bermain sambil belajar" adalah slogan yang biasa kita dengar di lingkungan sekolah anak usia dini. Slogan itu mempunyai makna yang sangat luas dan arti yang mendalam untuk anak-anak dalam menghadapi situasi atau persiapan belajar mereka di dalam kelas atau di lingkungan sekitarnya, belajar dengan cara yang menyenangkan, ceria, gembira, bahagia, tersenyum, tertawa tapi tetap satu tujuan yaitu hasil belajar yang optimal. Anak usia dini adalah sosok manusia yang akan bertumbuh dan berkembang dengan segudang mimpi, dimana mimpi-mimpi itu akan mereka wujudkan ketika mereka tumbuh dewasa dengan pribadi yang bahagia, karena dengan pribadi bahagialah dunia ini akan di penuhi dengan warna warna yang indah.

Mimpi itu akan anak pelajari dan temukan cara belajar berbagai macam temuan dan percobaan yang akan mereka lalui di sekolah, rumah, alam sekitar serta di lingkungan manapun. Anak akan mengeksplorasi apa yang mereka temukan. Sebagai manusia dewasa yang ada di sekitar mereka tentu kita sangat berperan penting bagi pertumbuhan dan perkembangan mereka sadar tidak sadar mau tidak mau, sebagai orang tua dan pendidik yang profesional kita tentunya akan mengarahkan segala bentuk belajar mereka dengan baik, menyalurkan keinginannya memahami karakteristik, dan menyentuh hatinya dengan kasih sayang. Anak usia dini adalah manusia yang penuh kejutan mereka unik satu persatu diantara mereka tidaklah sama, mereka memiliki perbedaan dan kekuatan yang sangat istimewa, oleh sebab itu slogan "Bermain Sambil Belajar" yang ada di sekolah pendidikan anak usia sangatlah tepat, karena anak usia dini tidak bisa belajar jika mereka tidak bermain dan mengekspresikan apa yang menjadi keinginan dan kebiasaannya.
Kegiatan belajar pada anak usia dini meliputi beberapa aspek perkembangan salah satu di antaranya adalah aspek kognitif yang jika di pelajari semua, salah satunya adalah tentang berhitung (matematika) disini anak usia dini harus mengenal tentang berhitung karena berhitung sangat dekat dengan kehidupan sehari hari anak anak contohnya seperti mengenal besar kecil, pendek panjang, lama sebentar, berapa, dan lain sebagainya.

Membahas tentang matematika tidak akan terlepas dari persamaan dan perbedaan dari hasil data atau informasi yang diterima juga memahami tentang konsep berhitung, mengenal angka, hasil atau jumlah, pola, ruang, batas awal dan akhir, perbandingan besar dan kecil. Bukan hanya itu saja, tetapi yang diperlukan dalam mengenal matematika adalah dibutuhkannya guru yang kreatif dan inovatif. Selain itu hal yang sangat penting yakni pentingnya pendekatan atau strategi model yang dilakukan oleh guru sehingga anak-anak dapat memahami pembelajaran matematika (Komala, 2019 hlm. 90).

Menurut Khadijah (2016, hlm. 146) mengemukakan prinsip-prinsip dalam menerapkan permainan berhitung di taman kanak kanak yaitu, permainan berhitung diberikan secara bertahap, di awali dengan berhitung benda benda atau pengalaman peristiwa konkrit yang di alami melalui pengamatan terhadap alam sekitar dan melalui tingkat kesukarannya, misalnya dari konkrit ke abstrak, mudah ke sukar, dan mulai dari yang sederhana ke yang lebih kompleks.

Sebenarnya jika dibayangkan pembelajaran berhitung untuk anak usia dini mungkin cukup mudah, tapi berhubung anak usia dini adalah anak yang butuh belajar secara langsung dan media pembelajaran yang nyata, maka 


\section{JURMAL GERIA}

ISSN : 2614-6347 (Print) 2714-4107 (Online)

Vol.2 | No.6 | September 2019

pastilah pembelajaran berhitung ini membutuhkan penyampaian yang tepat karena jika terjadi satu kesalahan atau kerancuan pada saat penyampaian, maka tidak bisa dihindari akan terjadi penolakan secara spontan dari anak anak

Maka dari pada itu disarankan bagi fasilitator / pendidik untuk lebih hati hati bagaimana cara menyampaikan yang baik dan tepat, agar anak anak tetap dalam suasana senang tidak tertekan dan masih dalam tujuan yang sama atau mencapai target pembelajaran yang diharapakan bersama.

\section{METODOLOGI}

Ruseffendi

(2010:52),

mengemukakan bahwa pada quasi eksperimen ini subjek tidak dikelompokkan secara acak, tetapi peneliti menerima keadaan subjek seadanya. (Hendriana, 2017: 14). Metode yang digunakan dalam penelitian ini adalah metode deskriptif dengan pertimbangan bahwa metode ini merupakan cara penelitian dengan menggambarkan peristiwa yang ada pada masa sekarang atau yang sedang terjadi.

Desain penelitian yang digunakan dalam penelitian ini adalah quasi eksperimen. Hal ini didasarkan tujuan penelitian quasi eksperimen yaitu menyelidiki kemungkinan saling hubungan sebab akibat dengan cara mengadakan intervensi atau mengenakan perlakuan kepada satu atau lebih kelompok eksperimen, kemudian hasil (akibat) dari intervensi tersebut dibandingkan dengan kelompok yang tidak dikenakan perlakuan (kelompok kontrol).

Bentuk desain penelitian yang dipakai adalah non-equivalent control group design dengan ciri:

a. Ada kelompok eksperimen dan kelompok kontrol.

b. Subjek penelitian diambil tidak secara acak dari populasi tetapi diambil seluruh subjek dari kelompok yang telah terbentuk secara alami.

Metode penelitian kuasi eksperimen dengan desain non-equivalent control group design yang digunakan oleh peneliti bertujuan untuk mengetahui suatu pengaruh dari suatu metode pembelajaran yang penerapannya menggunakan media sebagai sumber belajar pada pendidikan anak usia dini. Metode kuasi eksperimen ini membantu peneliti untuk mendapatkan hasil nyata dalam bentuk angka sebagai hasil perthitungan dari penerapan menggunakan metode bermain jari angka untuk meningkatkan kemampuan dalam berhitung. Populasi dalam penelitian ini adalah anak kelompok kelas B di Raudhatul Athfal yang menjadi kelas kontrol (kelompok B1) dan kelas ekperimen (kelompok B2).

Tabel 1

Sampel Penelitian

\begin{tabular}{|c|c|c|c|c|}
\hline No & Kelas & L & P & jumlah \\
\hline 1 & B1 & 8 & 10 & 18 \\
\hline 2 & B2 & 8 & 10 & 18 \\
\hline & Jml & 16 & 20 & 36 \\
\hline
\end{tabular}

\section{HASIL DAN PEMBAHASAN}

\section{Hasil}

Hasil Penelitian Penerapan Metode Bermain Jari Angka Untuk Meningkatkan Kemampuan Berhitung Anak Usia Dini Pada Kelompok B Sebelum Penerapan Metode Eksperimen, terlebih dahulu dilakukan pre test yang dilakukan dengan observasi hasil yang didapatkan menunjukan bahwa sebelum penerapan metode eksperimen diperoleh bahwa kemampuan berhitung anak usia dini pada kelompok B masih rendah. Hasil observasi yang diperoleh adalah 


\section{JURNAL GERIA}

ISSN : 2614-6347 (Print) 2714-4107 (Online)

Vol.2 | No.6 | September 2019

sebagai berikut : Pada pretest kelas eksperimen terdapat $(8 \%)$ pada kriteria $\mathrm{BB},(57 \%)$ pada kriteria $\mathrm{MB}$, pada kriteria BSH terdapat (35\%).
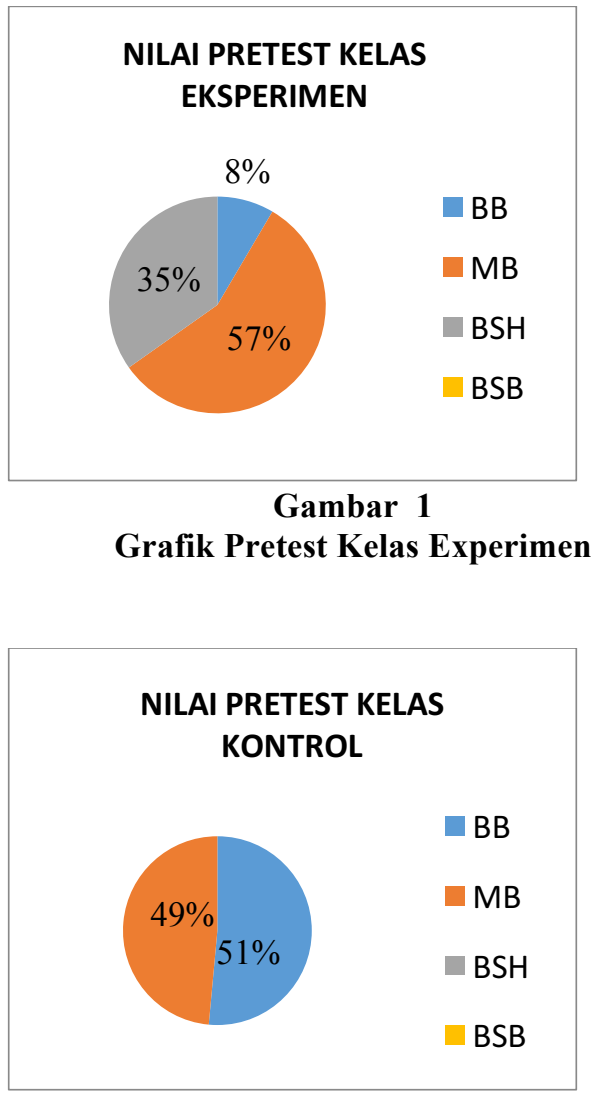

Gambar 2

\section{Grafik Pretest Kelas Kontrol}

Hasil penelitian post test ini di lakukan setelah diberikan treatment / penerapan metode eksperimen. Hasil post test Penerapan Metode Bermain Jari Angka Untuk Meningkatkan Kemampuan Berhitung Anak Usia Dini Pada Kelompok B Setelah Penerapan Metode Eksperimen meningkat, karena dari hasil observasi, di peroleh adalah sebagai berikut : Pada kriteria BSH (43\%), yang berada pada kriteria MB (55\%) dan (2\%) pada kriteria BB.

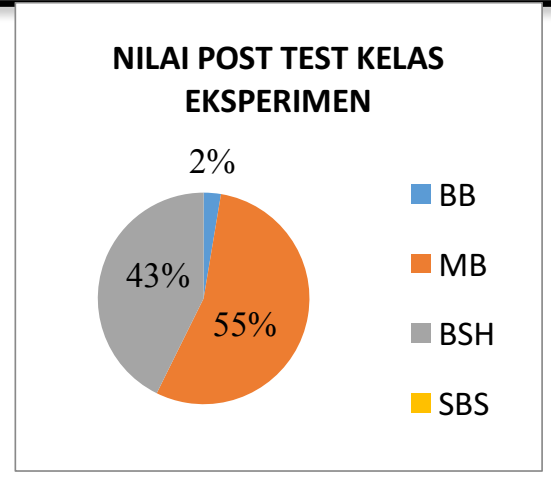

Gambar 3

Grafik Post test Kelas Experimen

\section{NILAI POSTTEST KELAS KONTROL}

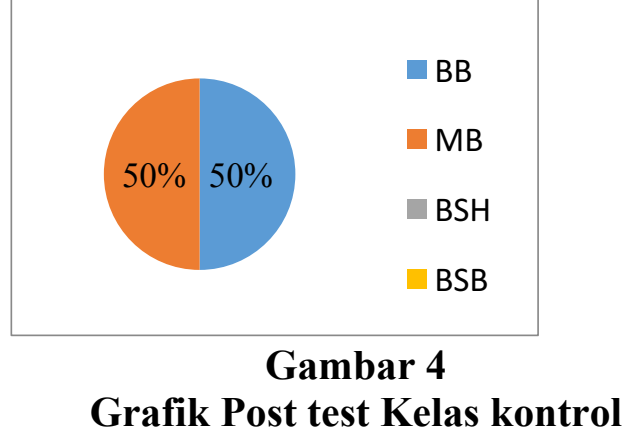

\section{Pembahasan}

Dari hasil penelitian yang dilakukan oleh peneliti di RA Alkaromah cimahi di atas dapat disimpulkan bahwa sesudah diberikam treatment metode bermain jari angka, hasil perkembangan anak - anak meunjukan hasil yang lebih baik dari sebelum di berikan metode bermain jari angka.

Penelitian tentang penggunaan metode jari angka ini telah di terapkan oleh Ratna Puspita indah (2015) dari STMIK Duta Bangsa Surakarta, hanya perbedaan treatmentnya diberikan pada jenjang penididikan dasar. Hasil penelitian menunjukan bahwa kontribusi langsung, metode bermain jari angka pada rata-rata nilai yang diperoleh siswa sebelum mengikuti pelatihan jari angka yaitu dari rata-rata 70,225 menjadi 76,225. Hasil tersebut menjadi bukti empiris adanya 


\section{JURNAL GERIA}

ISSN : 2614-6347 (Print) 2714-4107 (Online)

Vol.2 | No.6 | September 2019

pengaruh metode jarimatika terhadap hasil belajar matematika siswa.

Begitu juga dengan hasil yang dilakukan oleh peneliti pada penelitian penerapan metode bermain jari angka menunjukan hasil 31,7500. Sebelum diberikan treatmen dan diperoleh hasil 32,0625 setelah diberikan treatmen. Hal ini menunjukan bahwa kemampuan berhitung pada anak usia dini mengalami peningkatan.

\section{KESIMPULAN}

Berdasarkan hasil penelitian dapat disimpulkan bahwa Penerapan Metode bermain jari angka untuk meningkatkan kemampuanberhitung pada anak usia dini mengalami peningkatan.

\section{DAFTAR PUSTAKA}

Hendriana, H., Afrilianto, M, M.Pd. Maret (2017). Langkah Praktis Penelitian Tindakan Kelas Bagi Guru. PT REFIKA ADITAMA.
Indah, P. (Jurnal of Ratna Puspita Indah, volume 8, 1 september 2015). Efektivitas Metode Jarimatika Untuk Meningkatkan Kemampuan Berhitung Siswa Sekolah Dasar Kelas III. [Di akses pada tanggal 29 Maret 2019].

Khadijah, Dr.Hj.M.Ag. Maret (2016). Pengembangan Kognitf Anak Usia Dini. MEDAN:PERDANA PUBLISHING.

Komala, Santana, F.D.T, Hendriana. 2019. Kemampuan Guru Membangun Literasi Etnomatematika Anak di TK Al Hikmah Mujadhidin dan TK Kartika XIX - 3 Cimahi. Jurnal Islamic Early Childhood Education. Vol. 4 No.1 Tahun 2019. 89 - 94. [diunduh tanggal 14 Agustus 2019]. 